\title{
Carolignans from the Aerial Parts of Euphorbia sikkimensis and Their Anti-HIV Activity
}

\author{
Cheng Jiang ${ }^{\dagger}$, Pan Luo ${ }^{\dagger}$, Yu Zhao ${ }^{\ddagger}$, Jialing Hong ${ }^{\dagger}$, Susan L. Morris-Natschke ${ }^{\ddagger}$, Jun $\mathrm{Xu}^{\dagger}$, \\ Chin-Ho Chen $\$$, Kuo-Hsiung Lee ${ }^{*}, \neq, \perp$, and Qiong Gu ${ }^{*}, \dagger, \ddagger$ \\ $\dagger$ \\ $\ddagger$ \\ $\S$ \\ $\perp$
}

\section{Abstract}

Seven new carolignans, including two pairs of enantiomers $( \pm)$-erythro- $7^{\prime}$-methylcarolignan $\mathrm{E}$ $(\mathbf{1} \mathbf{a} / \mathbf{1 b})$ and $( \pm)$-threo-7'-methylcarolignan E (2a/2b), (+)-threo-carolignan E (3a), (+)-erythrocarolignan $\mathrm{E}(\mathbf{4 a})$, and (-)-erythro-carolignan $\mathrm{Z}(\mathbf{5})$, together with four known lignans $(\mathbf{3 b}, \mathbf{4 b}, \mathbf{6}$, and 7) and six polyphenols (8-13) were isolated from the aerial parts of Euphorbia sikkimensis. The structures of the new compounds were elucidated by spectroscopic analysis, and their absolute configurations were determined by electronic circular dichroism calculations. Seven of the isolates were examined for anti-HIV effects, and compounds $\mathbf{1 a}$ and $\mathbf{1 b}$ showed moderate antiHIV activity with $\mathrm{EC}_{50}$ values of 6.3 and $5.3 \mu \mathrm{M}$.
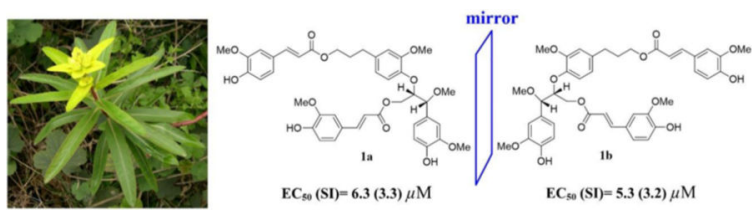

\begin{abstract}
The genus Euphorbia belongs to the family Euphorbiaceae, which is characterized by production of a white, milky latex that is somewhat toxic. The family contains about 300 genera and 7000 species. Euphorbia is one of the largest genera in the Euphorbiaceae family, with about 1600 species. Numerous chemical studies on the Euphorbia genus have
\end{abstract}

\footnotetext{
*Corresponding Authors Tel: 919-962-0066. Fax: 919-966-3893. khlee@unc.edu (K.-H. Lee). Tel/Fax: +86-20-39943077. guqiong@mail.sysu.edu.cn (Q. Gu)..

The authors declare no competing financial interest.

ASSOCIATED CONTENT

Supporting Information The Supporting Information is available free of charge on the ACS Publications website at DOI: 10.1021/ acs.jnatprod.5b01012.

UV, IR, MS, and 1D and 2D NMR for compounds 1a, 1b, 2a, 2b, 3a, 4a, and $\mathbf{5}$ (PDF)

DEDICATION

Dedicated to Professors John Blunt and Murray Munro, of the University of Canterbury, for their pioneering work on bioactive marine natural products.

Special Issue: Special Issue in Honor of John Blunt and Murray Munro
} 
been performed. ${ }^{1,2}$ Euphorbia sikkimensis Boiss. has been used to treat poisoning, malaria, rheumatism, and jaundice. ${ }^{3}$ In 2013, new and known diterpenes, triterpenoids, tocopherol derivatives, and other compounds were isolated. ${ }^{4,5}$ Two diterpenoids showed antiproliferative effects against the A549 cancer cell line, while (-)-bornyl ferulate exhibited antiangiogenic activity in a zebrafish model. ${ }^{5}$

In a continuing search for anti-HIV natural products from herbal medicinal plants, anti-HIV screening showed that an EtOAc-soluble fraction from an ethanol extract of the aerial parts of E. sikkimensis had an $\mathrm{EC}_{50}$ value of $2.5 \mu \mathrm{g} / \mathrm{mL}$ and an SI (selective index) value of more than 8.3. Prior literature reported that diterpenoids from Euphorbia showed potent anti-HIV activity at the nanomolar level, ${ }^{6,7}$ whereas one of these diterpenoids, a phorbol ester, also showed tumor-promoting activity. ${ }^{8}$ These results encouraged us to investigate the anti-HIVactive constituents of the EtOAc-soluble fraction, which led to the isolation and characterization of seven new lignans (1-7) and six polyphenols (8-13). Compounds 1a and 1b showed moderate anti-HIV activity with $\mathrm{EC}_{50}$ values of 6.3 and $5.3 \mu \mathrm{M}$, respectively. Herein are reported details of the isolation, structural elucidation, and anti-HIV activity of these compounds.

The known compounds were identified as $(-)-\left(7^{\prime} R, 8^{\prime} S\right)$-erythro-carolignan E $(\mathbf{3 b}),{ }^{9,10}(-)$ $\left(7^{\prime} S, 8^{\prime} S\right)$-threo-carolignan E (4b) ${ }^{9,10}$ threo-guaiacylglycerol- $\beta$ - $O$ - $4^{\prime}$-dihydroconiferyl alcohol (6), ${ }^{11,12}$ erythro-guaiacylglycerol- $\beta$-O- $4^{\prime}$-dihydroconiferyl alcohol (7), ${ }^{11,12}(E)$ ferulic acid (8), ${ }^{13,14}$ ethyl ferulate (9), ${ }^{14}$ protocatechuic acid (10), ${ }^{15,16}$ vanillic acid (11), ${ }^{17,18}$ methyl gallate (12) ${ }^{19}$ and ethyl gallate (13), ${ }^{19}$ based on spectroscopic data analysis and comparison with reported literature values.

\section{RESULTS AND DISCUSSION}

Compound $1(\mathbf{1 a} / \mathbf{1 b})$ was obtained as a white, amorphous solid. A molecular formula of $\mathrm{C}_{41} \mathrm{H}_{44} \mathrm{O}_{13}$ was deduced from a quasimolecular ion peak at $\mathrm{m} / \mathrm{z} 743.27039$ (calcd 743.27091) observed in the negative HRESIMS. The IR spectrum showed absorption bands for $\mathrm{OH}\left(3407 \mathrm{~cm}^{-1}\right)$, carbonyl $\left(1704 \mathrm{~cm}^{-1}\right)$, and aromatic groups $(1599,1514$, and 1460 $\left.\mathrm{cm}^{-1}\right)$. The ${ }^{1} \mathrm{H}$ NMR spectrum showed two pairs of doublets at $\delta_{\mathrm{H}} 7.59(1 \mathrm{H}, \mathrm{d}, J=15.9 \mathrm{~Hz}$, H-7'"') and $6.27\left(1 \mathrm{H}, \mathrm{d}, J=15.9 \mathrm{~Hz}, \mathrm{H}-8^{\prime \prime \prime}\right) ; 7.48(1 \mathrm{H}, \mathrm{d}, J=15.9 \mathrm{~Hz}, \mathrm{H}-7)$ and $6.23(1 \mathrm{H}, \mathrm{d}$, $J=15.9 \mathrm{~Hz}, \mathrm{H}-8)$, together with six aromatic protons (ring A: $\delta_{\mathrm{H}} 7.00(1 \mathrm{H}, \mathrm{d}, J=1.8 \mathrm{~Hz}$, H-2'"'), $6.91\left(1 \mathrm{H}, \mathrm{d}, J=8.1 \mathrm{~Hz}, \mathrm{H}-5^{\prime \prime \prime}\right), 7.05\left(1 \mathrm{H}, \mathrm{dd}, J=1.8,8.1 \mathrm{~Hz}, \mathrm{H}-6^{\prime \prime \prime}\right)$; ring C: $\delta_{\mathrm{H}} 7.02$ $(1 \mathrm{H}, \mathrm{d}, J=1.9 \mathrm{~Hz}, \mathrm{H}-2), 6.85(1 \mathrm{H}, \mathrm{d}, J=8.2 \mathrm{~Hz}, \mathrm{H}-5), 7.05(1 \mathrm{H}, \mathrm{dd}, J=1.9,8.2 \mathrm{~Hz}, \mathrm{H}-6))$. The ${ }^{13} \mathrm{C}$ NMR spectrum exhibited two conjugated carbonyl carbons at $\delta_{\mathrm{C}} 167.1$ and 167.5 $\mathrm{ppm}$. The above data indicated the presence of two feruloyl moieties. The ${ }^{13} \mathrm{C}$ NMR spectrum (Figure S6, Supporting Information) also displayed two oxymethylene $\left(\mathrm{CH}_{2} \mathrm{O}, \delta_{\mathrm{C}}\right.$ 63.9), two methylene $\left(\mathrm{CH}_{2}, \delta_{\mathrm{C}} 32.1,30.6\right)$, and two oxymethine $\left(\mathrm{CHO}, \delta_{\mathrm{C}} 83.5,82.3\right)$ signals, and the COSY correlations (Figure 1) suggested one $\mathrm{CH}_{2} \mathrm{O}-\mathrm{CH}_{2}-\mathrm{CH}_{2}$ fragment and one $\mathrm{CH}_{2} \mathrm{O}-\mathrm{CHO}-\mathrm{CHO}$ group. The ${ }^{1} \mathrm{H}$ and ${ }^{13} \mathrm{C}$ NMR data (Tables 1 and 2 ) also indicated two 1,3,4-trisubstituted aromatic units (rings $\mathrm{B}$ and $\mathrm{D}$ ) and five methoxy groups. HMBC correlations (Figure 1$)$ of $\mathrm{H}-9^{\prime \prime}\left(\delta_{\mathrm{H}} 4.15,2 \mathrm{H}, \mathrm{t}, J=6.5 \mathrm{~Hz}\right)$ with C-9 ${ }^{\prime \prime \prime}\left(\delta_{\mathrm{C}} 167.5\right)$ and H-9' $\left(\delta_{\mathrm{H}} 4.11,1 \mathrm{H}, \mathrm{dd}, J=4.7,11.6 \mathrm{~Hz} ; 4.31,1 \mathrm{H}, \mathrm{dd}, J=2.8,11.6 \mathrm{~Hz}\right)$ with $\mathrm{C}-9\left(\delta_{\mathrm{C}} 167.1\right)$ showed that two feruloyl units were connected at C-9 and C-9'". All of the above data were 
closely similar to those of the known compound erythro-carolignan E, ${ }^{9,10}$ except for an additional methoxy group in the new compound. The position of this methoxy group at C-7' was confirmed from the $\mathrm{HMBC}$ correlation of $\mathrm{MeO}\left(\delta_{\mathrm{H}} 3.27, \mathrm{~s}\right)$ with $\mathrm{C}-7^{\prime}\left(\delta_{\mathrm{C}} 83.5\right.$, d). Its relative configuration was established on the basis of NOESY correlations (Figure 2) and interpretation of ${ }^{1} \mathrm{H}-{ }^{1} \mathrm{H}$ coupling constants. A coupling constant of $15.9 \mathrm{~Hz}$ between $\mathrm{H}-8$ $\left(8^{\prime \prime \prime}\right)$ and H-7 ( $\left.7^{\prime \prime \prime}\right)$ suggested an $E$-configuration for $\Delta^{7}$ and $\Delta^{7 \prime \prime \prime}$. The coupling constant between $\mathrm{H}-7^{\prime}$ and $\mathrm{H}-8^{\prime}(3.0 \mathrm{~Hz})$ implied an erythro-configuration of these two protons. ${ }^{20-22}$ Thus, compound $\mathbf{1}$ (erythro-7'-methylcarolignan E) was fully identified.

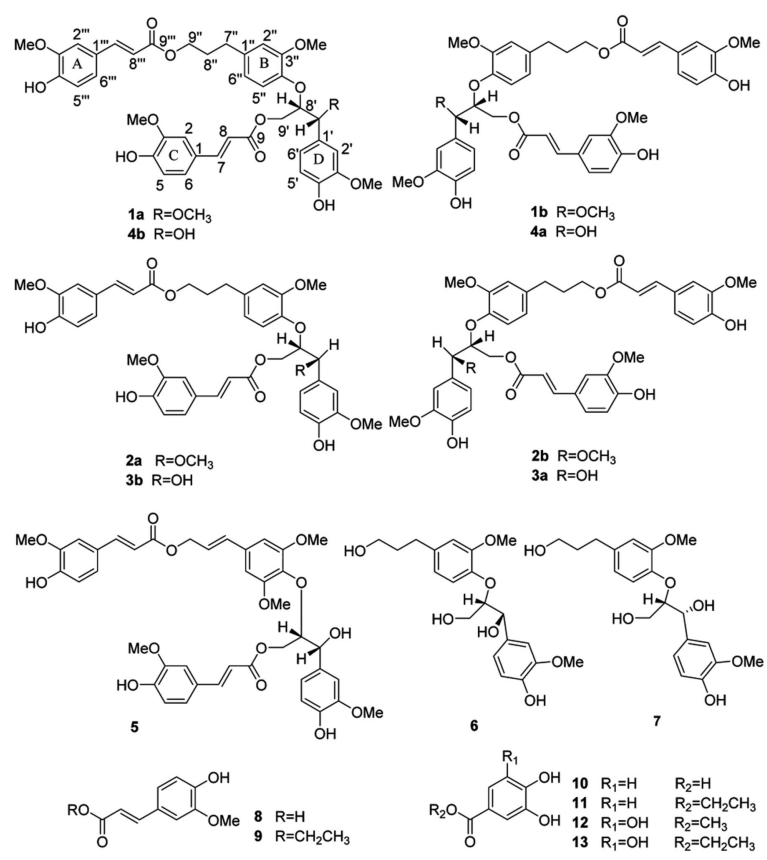

The specific rotation of $\mathbf{1}$ approached zero, and no Cotton effect was found in the electronic circular dichroism (ECD) spectrum of $\mathbf{1}$, indicating a racemic mixture. Subsequent chiral resolution of $\mathbf{1}$ afforded the anticipated enantiomers $\mathbf{1 a}$ and $\mathbf{1 b}$, which showed mirror imagelike ECD curves (Figure $3 a$ ) and specific rotations $\left(\mathbf{1 a}:[a]^{20}{ }_{\mathrm{D}}-16.2 ; \mathbf{1 b}:[a]^{20} \mathrm{D}+17.1\right)$. In order to define the absolute configuration of the enantiomers $\mathbf{1 a}$ and $\mathbf{1 b}$, ECD calculations were performed for the two configurations $\left(7^{\prime} R, 8^{\prime} S\right)$ - and $\left(7^{\prime} S, 8^{\prime} R\right)-\mathbf{1}$ using the Gaussian 09 program at the TD-DFT-B3LYP/6-311++G(d,p) level in MeCN. The calculation for the $7{ }^{\prime} R$, $8^{\prime} S$ enantiomer agreed with the experimental ECD data (Figure 3a) of 1a. Thus, 1a has a $7^{\prime} R, 8^{\prime} S$-configuration. The calculated ECD spectrum for the $7^{\prime} S, 8^{\prime} R$-configuration was in good accordance with the experimental spectrum of $\mathbf{1 b}$ (Figure $3 a$ ). Consequently, the absolute configuration of $\mathbf{1 b}$ was unambiguously assigned with the $7^{\prime} S, 8^{\prime} R$-configuration. Thus, compounds $\mathbf{1 a}$ and $\mathbf{1 b}$ were given the trivial names $(-)-\left(7^{\prime} R, 8^{\prime} S\right)$-erythro- $7^{\prime}$ methylcarolignan $\mathrm{E}$ and $(+)-\left(7^{\prime} S, 8^{\prime} R\right)$-erythro- $7^{\prime}$-methylcarolignan $\mathrm{E}$, respectively.

Compound $2(\mathbf{2} \mathbf{a} / \mathbf{2} \mathbf{b})$ was isolated as a white, amorphous solid, having the same molecular formula as that of $\mathbf{1}$ as deduced from HRESIMS. The NMR data of $\mathbf{2}$ were almost identical to those of $\mathbf{1}$, except for a slight discrepancy in the positions of the oxygenated methines (C-7' and C-8'). Detailed 2D NMR analysis (Figures S18-20, Supporting Information) 
revealed that $\mathbf{2}$ shares the same planar structure as that of $\mathbf{1}$, indicating $\mathbf{2}$ to be a stereoisomer of 1 with the configuration changed at $\mathrm{C}-7^{\prime}$ or $\mathrm{C}-8^{\prime}$. A threo-configuration of 2 was further determined by the coupling constants between $\mathrm{H}-7^{\prime}$ and $\mathrm{H}-8^{\prime}(6.3 \mathrm{~Hz}){ }^{20,23}$ Compound 2 also has negligible optical activity and an ECD spectrum devoid of Cotton effects. Chiral isolation of $\mathbf{2}$ afforded the enantiomers $\mathbf{2} \mathbf{a}$ and $\mathbf{2 b}$. By comparison of the calculated ECD spectra of $7^{\prime} S, 8^{\prime} S-\mathbf{2}$ and $7^{\prime} R, 8^{\prime} R-\mathbf{2}$ with the experimental data of $\mathbf{2 a}$ and $\mathbf{2 b}$ (Figure $3 \mathrm{~b}$ ), the absolute configurations of $\mathbf{2} \mathbf{a}$ and $\mathbf{2} \mathbf{b}$ were assigned as $7^{\prime} S, 8^{\prime} S$ and $7^{\prime} R, 8^{\prime} R$. Compounds $\mathbf{2 a}$ and $\mathbf{2 b}$ were given the trivial names (-)- $\left(7^{\prime} S, 8^{\prime} S\right)$-threo- $7^{\prime}$-methylcarolignan $\mathrm{E}$ and $(+)-\left(7^{\prime} R\right.$, $\left.8^{\prime} R\right)$-threo- $7^{\prime}$-methylcarolignan E, respectively.

Compound 3 (3a/3b), obtained as a white, amorphous solid, gave a molecular formula $\mathrm{C}_{40} \mathrm{H}_{42} \mathrm{O}_{13}$ determined from the HRESIMS ion at $\mathrm{m} / z$. $729.2542[\mathrm{M}-\mathrm{H}]^{-}$(calcd $\mathrm{C}_{40} \mathrm{H}_{41} \mathrm{O}_{13}$ ). Its NMR data (Tables 1 and 2) were almost identical to those of threocarolignan E. ${ }^{9,10}$ Compound $\mathbf{3}$ showed a negligible specific rotation and CD spectrum, indicating it to be a racemic mixture. Subsequent chiral separation of $\mathbf{3}$ afforded a pair of enantiomer 3a and 3b, which had opposite ECD curves (Figure 3c) and optical rotations (3a: $[a]^{20} \mathrm{D}+30.4$; 3b: $\left.[a]^{20} \mathrm{D}-29.8\right)$. The absolute configurations of $\mathbf{3 a}$ and $\mathbf{3 b}$ were determined using the same methods as described in $\mathbf{1 a}$ and $\mathbf{1 b}$. Thus, 3a was defined as $(+)-\left(7^{\prime} R, 8^{\prime} R\right)$ threo-carolignan $\mathrm{E}$, and $\mathbf{3 b}$ was identified as the known compound (-)-(7'S, $\left.8^{\prime} S\right)$-threocarolignan E. 10

Compound 4 (4a/4b), a white, amorphous solid, showed the same molecular formula as that of 3. The two compounds had similar NMR data, except for the position of the C-7' and C-8' oxygenated methines. Detailed 2D NMR analysis confirmed that $\mathbf{4}$ and $\mathbf{3}$ shared the same planar structure, indicating that $\mathbf{4}$ is a stereoisomer of $\mathbf{3}$ with a different orientation of the substituents at $\mathrm{C}-7^{\prime}$ or $\mathrm{C}-8^{\prime}$. The coupling constant $J_{7^{\prime}, 8^{\prime}}$ was $3.3 \mathrm{~Hz}$, so therefore the relative configuration at $\mathrm{C}-7^{\prime}$ and $\mathrm{C}-8^{\prime}$ was erythro. Compound 4 also showed a negligible optical activity and an ECD spectrum devoid of Cotton effects. Chiral isolation of $\mathbf{4}$ afforded the enantiomers $4 \mathbf{a}$ and $\mathbf{4 b}$. By comparison of the calculated ECD spectra of the $7^{\prime} R, 8^{\prime} S$ and $7^{\prime} S$, $8^{\prime} R$ configurations of $\mathbf{4}$ with the experimental data of $\mathbf{4 a}$ and $\mathbf{4 b}$ (Figure $3 \mathrm{~d}$ ), the absolute configurations of $\mathbf{4 a}$ and $\mathbf{4 b}$ were assigned as $7^{\prime} S, 8^{\prime} R$ and $7^{\prime} R, 8^{\prime} S$, respectively. Thus, $4 \mathbf{a}$ was identified as (+)-( $\left.7^{\prime} S, 8^{\prime} R\right)$-erythro-carolignan $\mathrm{E}$, and $\mathbf{4 b}$ was elucidated as the known compound (-)-( $\left.7^{\prime} R, 8^{\prime} S\right)$-erythro-carolignan E. ${ }^{10}$

Compound 5, a white, amorphous solid, gave the molecular formula $\mathrm{C}_{41} \mathrm{H}_{42} \mathrm{O}_{14}$ as determined by the HRESIMS ion at $m / z$ 757.24921 $[\mathrm{M}-\mathrm{H}]^{-}$(calcd 757.25018). The NMR data of $\mathbf{5}$ were similar to those of $\mathbf{1}$ with an additional methoxy group in the B-ring and two olefinic carbons $\left(\delta_{\mathrm{C}} 134.0,123.8\right)$ rather than two methylene signals. The B-ring proton signals at $\delta_{\mathrm{H}} 6.60(2 \mathrm{H}, \mathrm{d}, J=1.8 \mathrm{~Hz})$ implied a symmetrical 1,3,4,5-tetrasubstituted aromatic ring, consistent with the location of the additional methoxy group in $\mathbf{5}$ at $\mathrm{C}-5^{\prime \prime}$. This assignment was confirmed by the $\mathrm{HMBC}$ correlations (Figure 4$)$ of the methoxy protons $\left(\delta_{\mathrm{H}}\right.$ 3.90) with C-6" ( $\left.\delta_{\mathrm{C}} 103.9\right)$. The location of the double bond was determined by HMBC correlation from the olefinic protons $\left(\delta_{\mathrm{H}} 6.30, \mathrm{H}-8^{\prime \prime}\right)$ with $\mathrm{C}-1^{\prime \prime}\left(\delta_{\mathrm{C}} 130.9\right)$. The overall structure was further established by analysis of its 2D NMR spectra (Figures S46-49, Supporting Information). An erythro-configuration of $\mathbf{5}$ was further determined by the 
coupling constants between $\mathrm{H}-7^{\prime}$ and $\mathrm{H}-8^{\prime}(3.1 \mathrm{~Hz}){ }^{20-22}$ The experimental ECD spectrum of 5 showed an ECD curve with Cotton effects around $324(-), 290(-)$, and $242(+) \mathrm{nm}$ (Figure 3e). The absolute configuration of $\mathbf{5}$ was assigned as $R, S$ through comparison with the calculated ECD spectra of $\left(7^{\prime} R, 8^{\prime} S\right)-5$ (Figure 3e). Thus, 5 was elucidated as (-)- $7^{\prime} R, 8^{\prime} S$ erythro-carolignan $\mathrm{Z}$.

Seven compounds (1a, $\mathbf{1 b}, \mathbf{2 a}, \mathbf{2 b}, \mathbf{5}, \mathbf{8}$, and $\mathbf{9})$ were tested for in vitro inhibitory effects against HIV-1 replication in MT4 cell lines, with AZT used as the positive control. One pair of enantiomers, 1a and $\mathbf{1 b}$, showed more potent anti-HIV activity.

\section{EXPERIMENTAL SECTION}

\section{General Experimental Procedures}

Optical rotations were measured on a PerkinElmer 341 automatic polarimeter. UV spectra were recorded using a Shimadzu UV-2450 spectrophotometer. CD spectra were obtained on an Applied Photophysics Chirascan spectrometer. IR spectra were determined on a Bruker Tensor 37 infrared spectrophotometer. The ${ }^{1} \mathrm{H}(400 \mathrm{MHz}),{ }^{13} \mathrm{C}(100 \mathrm{MHz})$, and 2D NMR spectra were obtained on a Bruker AM-400 with tetramethylsilane as an internal reference at $25^{\circ} \mathrm{C}$. Chemical shifts $(\delta)$ are expressed in ppm with reference to the solvent signals. HRESIMS were acquired on a Shimadzu LCMS-IT-TOF instrument, and the ESIMS data were measured on an Agilent 1200 series LC-MS/MS system. Macroporous resin D101 (Sinopharm Chemical Reagent Co. Ltd., Shanghai, People's Republic of China), RP-C18 silica gel (Fuji, 40-75 $\mu \mathrm{m}$ ), MCI gel CHP20P (75-150 $\mu \mathrm{m}$, Mitsubishi Chemical Corporation, Tokyo, Japan), silica gel (200-300 mesh, Marine Chemical Ltd., Qingdao, People's Republic of China), and Sephadex LH-20 (GE Healthcare Bio-Sciences AB, Sweden) were used for column chromatography. Analytical and semipreparative HPLC separation were carried out on an LC-20AT Shimadzu liquid chromatography system with a Zorbax SB-C18 column $(250 \times 9.4 \mathrm{~mm}, 5 \mu \mathrm{m})$ or an Agilent SB-C18 column connected with an SPD-M20A diode array detector. Semipreparative chiral HPLC separation was carried out on an LC-20AT Shimadzu liquid chromatography system with a Phenomenex Lux cellulose- 2 chiral-phase column $(250 \times 10 \mathrm{~mm}, 5 \mu \mathrm{m})$. Thin-layer chromatography (TLC) analysis was carried out on silica gel plates (Marine Chemical Ltd.). Fractions were monitored by TLC and visualized by heating plates sprayed with $5 \% \mathrm{H}_{2} \mathrm{SO}_{4}$ in EtOH. All solvents were of analytical grade (Guangzhou Chemical Reagents Company Ltd., Guangzhou, People's Republic of China).

\section{Plant Material}

The aerial parts of Euphorbia sikkimensis were collected at Longli County of the Qiannan Buyi National Minority Miao National Minority Autonomous Region, Guizhou Province, People's Republic of China, in July 2014. The sample was identified by Dr. Qingwen Sun from Guiyang College of Traditional Chinese Medicine, and a voucher specimen (GZQSY356) has been deposited at the School of Pharmaceutical Science, Sun Yat-sen University. 


\section{Extraction and Isolation}

The air-dried and powdered aerial parts $(20 \mathrm{~kg})$ of E. sikkimensis were extracted with $95 \%$ $\mathrm{EtOH}(3 \times 40 \mathrm{~L})$ at room temperature for $48 \mathrm{~h}$. The solvent was concentrated under reduced pressure to give a crude extract $(2.562 \mathrm{~kg})$. The $95 \% \mathrm{EtOH}$ extract was then suspended in $\mathrm{H}_{2} \mathrm{O}(2 \mathrm{~L})$ and successively partitioned with petroleum ether $(3 \times 8 \mathrm{~L})$, EtOAc $(3 \times 8 \mathrm{~L})$, and $n$ - $\mathrm{BuOH}(3 \times 8 \mathrm{~L})$ to yield three corresponding portions. The EtOAc-soluble extract $(334 \mathrm{~g})$ was chromatographed on D101 macroporous resin eluting with a step gradient of EtOH$\mathrm{H}_{2} \mathrm{O}(2: 8,5: 5,7: 3,10: 0)$ to afford four fractions (A-D). Fraction A was separated using $\mathrm{MCI}$ gel CHP20P eluting with an increasing gradient of $\mathrm{MeOH}-\mathrm{H}_{2} \mathrm{O}$ from $30 \%$ to $100 \%$ and then further purified by silica gel columns to give compounds $8(4 \mathrm{mg}), \mathbf{1 0}(6 \mathrm{mg}), \mathbf{1 1}$ $(20 \mathrm{mg}), \mathbf{1 2}(2.0 \mathrm{~g})$, and $\mathbf{1 3}(5.2 \mathrm{~g})$. Fraction B was subjected to an RP-18 column with $\mathrm{MeOH}-\mathrm{H}_{2} \mathrm{O}$ (30-100\%) as eluent to afford four subfractions (B1-B4). Fraction B1 (16.4 g) was chromatographed on a silica gel column using $\mathrm{CH}_{2} \mathrm{Cl}_{2}-\mathrm{MeOH}(1: 0,100: 1,15: 1)$ to yield six subfractions (B1a-B1f). Fraction B1c was submitted to separation over a Sephadex LH-20 column eluting with $\mathrm{CH}_{2} \mathrm{Cl}_{2}-\mathrm{MeOH}$ (1:1) to give four subfractions (B1c1-B1c4). Fraction B1c2 was further purified by semipreparative HPLC eluting with $\mathrm{MeOH}-\mathrm{H}_{2} \mathrm{O}$ (60:40) to produce compounds $3(10 \mathrm{mg})$ and $\mathbf{4}(6.2 \mathrm{mg})$. Fractions B1d and B1e were combined and further subjected to MPLC using $\mathrm{CH}_{2} \mathrm{Cl}_{2}-\mathrm{EtOAc}$ (50:1) and further purified with semipreparative HPLC eluting with $\mathrm{MeCN}-\mathrm{H}_{2} \mathrm{O}$ (55:45) to give compounds 1 ( $8.2 \mathrm{mg}$ ) and $2(15.8 \mathrm{mg})$. Compounds $5(10.2 \mathrm{mg}), \mathbf{6}(1.0 \mathrm{mg})$, and $7(0.8 \mathrm{mg})$ were isolated from fraction B1f by semipreparative HPLC with $\mathrm{MeCN}-\mathrm{H}_{2} \mathrm{O}$ (50:50). Fraction $\mathrm{C}$ was chromatographed over a silica gel-containing column eluting with $\mathrm{CH}_{2} \mathrm{Cl}_{2}-\mathrm{MeOH}$ (200:1, 20:1) to obtain compound $\mathbf{9}(\mathbf{4 m})$. Compounds $\mathbf{1 - 4}$ were further separated by semipreparative chiral HPLC $\left(\mathrm{CH}_{3} \mathrm{OH}-\mathrm{H}_{2} \mathrm{O}, 9: 1,3 \mathrm{~mL} / \mathrm{min}\right)$ to give $1 \mathrm{a}\left(3.5 \mathrm{mg}, t_{\mathrm{R}} 30.4\right.$ min), 1b (3.4 mg, $\left.t_{\mathrm{R}} 33.2 \mathrm{~min}\right), \mathbf{2 a}\left(7.3 \mathrm{mg}, t_{\mathrm{R}} 31.2 \mathrm{~min}\right), \mathbf{2 b}\left(5.7 \mathrm{mg}, t_{\mathrm{R}} 34.6 \mathrm{~min}\right), \mathbf{3 a}(2.9$ $\left.\mathrm{mg}, t_{\mathrm{R}} 28.2 \mathrm{~min}\right), \mathbf{3 b}\left(5.5 \mathrm{mg}, t_{\mathrm{R}} 25.7 \mathrm{~min}\right), \mathbf{4 a}\left(2.1 \mathrm{mg}, t_{\mathrm{R}}, 29.4 \mathrm{~min}\right)$, and $\mathbf{4 b}\left(2.5 \mathrm{mg}, t_{\mathrm{R}}\right.$, $26.8 \mathrm{~min})$, respectively.

(-)-(7'R,8'S)-erythro-7'-Methylcarolignan E (1a): white, amorphous solid; $[a]^{20}{ }_{\mathrm{D}}-16.2(c$ 0.1, $\mathrm{CHCl}_{3}$ ); UV (MeOH) $\lambda_{\max }(\log \varepsilon) 231$ (4.58), 288 (3.87), 327 (4.68) nm; ECD (MeCN) $\lambda_{\max }(\Delta \varepsilon) 232$ (1.03), $211(-3.72) \mathrm{nm}$; IR $v_{\max } 3407,2962,2930,2853,1704,1633,1599$, 1514, 1460, 1428, 1262, 1096, 1027, $803 \mathrm{~cm}^{-1} ;{ }^{1} \mathrm{H}$ NMR $\left(\mathrm{CDCl}_{3}, 400 \mathrm{MHz}\right)$ and ${ }^{13} \mathrm{C} \mathrm{NMR}$ $\left(\mathrm{CDCl}_{3}, 100 \mathrm{MHz}\right)$ data, see Tables 1 and 2; HRESIMS $\mathrm{m} / z$. $743.27039[\mathrm{M}-\mathrm{H}]^{-}$(calcd for $\left.\mathrm{C}_{41} \mathrm{H}_{43} \mathrm{O}_{13}, 743.27091\right)$.

(+)-(7'S,8 R)-erythro-7'-Methylcarolignan E (1b): white, amorphous solid; $[a]^{20} \mathrm{D}+17.1(c$ $\left.0.1, \mathrm{CHCl}_{3}\right)$; ECD (MeCN) $\lambda_{\max }(\Delta \varepsilon) 232$ (-1.03), 211 (3.80) nm; UV, IR, NMR, and HRESIMS were the same as those of $\mathbf{1 a}$.

(-)-(7'S, 8'S)-threo-7'-Methylcarolignan E (2a): white, amorphous solid; $[a]^{20} \mathrm{D}-35.1$ (c 0.2, $\mathrm{CHCl}_{3}$ ); UV (MeOH) $\lambda_{\max }(\log \varepsilon) 232$ (4.36), 288 (2.92), 326 (4.64) nm; ECD (MeCN) $\lambda_{\max }(\Delta \varepsilon) 325(-1.78), 295(-1.80), 240(-1.14) \mathrm{nm}$; IR $v_{\max } 3402,2961,2919,2850,1704$, 1633, 1597, 1514, 1464, 1428, 1263, 1097, 1028, $803 \mathrm{~cm}^{-1} ;{ }^{1} \mathrm{H}$ NMR (CDCl $\left.3,400 \mathrm{MHz}\right)$ and ${ }^{13} \mathrm{C} \mathrm{NMR}\left(\mathrm{CDCl}_{3}, 100 \mathrm{MHz}\right)$ data, see Tables 1 and 2; HRESIMS $m / z 743.26971$ [M $\mathrm{H}]^{-}\left(\right.$calcd for $\mathrm{C}_{41} \mathrm{H}_{43} \mathrm{O}_{13}, 743.27091$ ). 
(+)-(7'R, 8 R)-threo-7'-Methylcarolignan $E(\mathbf{2 b})$ : white, amorphous solid; $[a]^{20} \mathrm{D}+32.6(c$ $0.2, \mathrm{CHCl}_{3}$ ); $\mathrm{ECD}(\mathrm{MeCN}) \lambda_{\max }(\Delta \varepsilon) 325$ (1.73), 294 (1.76), 240 (1.17) nm; UV, IR, NMR, and HRESIMS were the same as those of $\mathbf{2 a}$.

(+)-(7R,8R)-threo-Carolignan E (3a): white, amorphous solid; $[a]^{20}{ }_{\mathrm{D}}+30.4(c$ 0.1, $\left.\mathrm{CHCl}_{3}\right)$; ECD (MeCN) $\lambda_{\max }(\Delta \varepsilon) 333(+1.08), 298(+1.34), 240(+1.58) \mathrm{nm} ; \mathrm{UV}(\mathrm{MeOH})$ $\lambda_{\max }(\log \varepsilon) 230$ (4.51), 284 (2.75), 320 (4.83) nm; IR $v_{\max } 3413,2940,2913,2852,1704$, $1631,1597,1513,1461,1430,1172,1097,1031,801 \mathrm{~cm}^{-1} ;{ }^{1} \mathrm{H}$ NMR $\left(\mathrm{CDCl}_{3}, 400 \mathrm{MHz}\right)$ and ${ }^{13} \mathrm{C}$ NMR $\left(\mathrm{CDCl}_{3}, 100 \mathrm{MHz}\right)$ data, see Tables 1 and 2; HRESIMS $m / z, 729.2542[\mathrm{M}-$ $\mathrm{H}]^{-}$(calcd for $\mathrm{C}_{40} \mathrm{H}_{41} \mathrm{O}_{13}, 729.2553$ ).

(-)-(7/S,8 S)-threo-Carolignan E (3b): white, amorphous solid; $[a]^{20}{ }_{\mathrm{D}}-29.8(c$ 0.1, $\mathrm{CHCl}_{3}$ ); ECD (MeCN) $\lambda_{\max }(\Delta \varepsilon) 334$ (-1.08), 298 (-1.32), 240 (-1.54) nm; UV, IR, NMR, and HRESIMS were the same as those of $\mathbf{3 a}$.

(+)-(7'S,8 R)-erythro-Carolignan E (4a): white, amorphous solid; $[a]^{20}{ }_{\mathrm{D}}+16.6(c 0.1$, $\left.\mathrm{CHCl}_{3}\right) ; \mathrm{ECD}(\mathrm{MeCN}) \lambda_{\max }(\Delta \varepsilon) 234(+3.18), 222(-1.22) \mathrm{nm} ; \mathrm{UV}(\mathrm{MeOH}) \lambda_{\max }(\log \varepsilon)$ 232 (4.36), 288 (2.92), 326 (4.64) nm; IR $\lambda_{\max }$ 3512, 2941, 2917, 2850, 1700, 1631, 1592, 1513, 1464, 1430, 1260, 1090, 1030, $802 \mathrm{~cm}^{-1} ;{ }^{1} \mathrm{H} \mathrm{NMR}\left(\mathrm{CDCl}_{3}, 400 \mathrm{MHz}\right)$ and ${ }^{13} \mathrm{C} \mathrm{NMR}$ $\left(\mathrm{CDCl}_{3}, 100 \mathrm{MHz}\right)$ data, see Tables 1 and 2; HRESIMS $m / z$ 729.2542 [M - H] $]^{-}$(calcd for $\left.\mathrm{C}_{40} \mathrm{H}_{41} \mathrm{O}_{13}, 729.2553\right)$.

(-)-(7R,8S)-erythro-Carolignan E (4b): white, amorphous solid; [ $a]^{20}{ }_{\mathrm{D}}-16.4$ (c 0.1, $\left.\mathrm{CHCl}_{3}\right)$; $\mathrm{ECD}(\mathrm{MeCN}) \lambda_{\max }(\Delta \varepsilon) 234(-3.20), 222(+1.21) \mathrm{nm}$; UV, IR, NMR, and HRESIMS were the same as those of $\mathbf{4 a}$.

(-)-(7R,8 S)-erythro-Carolignan Z (5): white, amorphous solid; $[a]^{23} \mathrm{D}-34.1$ (c 0.24, $\left.\mathrm{CHCl}_{3}\right) ; \mathrm{ECD}(\mathrm{MeCN}) \lambda_{\max }(\Delta \varepsilon) 324(-2.54), 290(-2.78), 242(+1.28) \mathrm{nm} ; \mathrm{UV}(\mathrm{MeOH})$ $\lambda_{\max }(\log \varepsilon) 219$ (6.76), 286 (3.40), 326 (4.31) nm; IR $\lambda_{\max } 3427,2963,2930,2853,1704$, $1632,1588,1514,1463,1427,1262,1152,1097,1022,801 \mathrm{~cm}^{-1} ;{ }^{1} \mathrm{H} \mathrm{NMR}\left(\mathrm{CDCl}_{3}, 400\right.$ $\mathrm{MHz})$ and ${ }^{13} \mathrm{C} \mathrm{NMR}\left(\mathrm{CDCl}_{3}, 100 \mathrm{MHz}\right)$ data, see Tables 1 and 2; HRESIMS $m / z$ 757.24921 $[\mathrm{M}-\mathrm{H}]^{-}$(calcd for $\mathrm{C}_{41} \mathrm{H}_{41} \mathrm{O}_{14}, 757.25018$ ).

\section{Multicycle Viral Replication in MT4 Cell Assay}

The anti-HIV-1 assay was performed as previously described. ${ }^{24}$ HIV-1 NL4-3 Nanolucsec at an infecting dose of $50 \mathrm{TCID}_{50} /$ well was used to infect MT4 cells $\left(1 \times 10^{5}\right.$ cells $\left./ \mathrm{mL}\right)$ in the presence of compounds at various concentrations in 96-well plates. On day 3 postinfection, supernatant samples were harvested and assayed for luciferase activity using the Promega Nano-Glo luciferase assay system. The antiviral potency is defined as the drug concentration that reduces the luciferase activity by $50 \%\left(\mathrm{EC}_{50}\right)$.

\section{Cytotoxicity Assay}

A CytoTox-Glo cytotoxicity assay (Promega) was used to determine the cytotoxicity of the isolates. MT4 cells were cultured in the presence of various concentrations of the compounds for 3 days. Cytotoxicity of the compounds was determined by following the 
protocol provided by the manufacturer. The $50 \%$ cytotoxic concentration $\left(\mathrm{CC}_{50}\right)$ was defined as the concentration that caused a 50\% reduction of cell viability.

\section{Supplementary Material}

Refer to Web version on PubMed Central for supplementary material.

\section{ACKNOWLEDGMENTS}

This study was supported in part by the National High-Tech R\&D Program of China (863 Program) (2012AA020307), the Guangdong Innovative Research Team Program (No. 2009010058), and the National Natural Science Foundation of China (No. 81173470). Partial support was also received from the National Institute of Allergy and Infectious Diseases (NIAID) Grant AI33066 (K.H.L.).

\section{REFERENCES}

1. Vasas A, Hohmann J. Chem. Rev. 2014; 114:8579-8612. [PubMed: 25036812]

2. Shi QW, Su XH, Kiyota H. Chem. Rev. 2008; 108:4295-4327. [PubMed: 18817355]

3. Fan JW, Yu L, Ma LZ, Guo N, Gao QS, Zhao QM, Zeng FL, Ge F, Wang QK, Deng XM, Zeng L. Chin. Agric. Sci. Bull. 2009; 25:1-7.

4. Yang DS, Zhang YL, Peng WB, Wang LY, Li ZL, Wang X, Liu KC, Yang YP, Li HL, Li XL. J. Nat. Prod. 2013; 76:265-269. [PubMed: 23327832]

5. Yang DS, Peng WB, Li ZL, Wang X, Wei JG, Liu KC, Yang YP, Li XL. Nat. Prod. Bioprospect. 2013; 3:112-116.

6. Vasas AL, Gyuris A, Minarovics J, Hohmann J. Planta Med. 2007; 73:947-947.

7. Pan LL, Fang PL, Zhang XJ, Ni W, Li L, Yang LM, Chen CX, Zheng YT, Li CT, Hao XJ, Liu HY. J. Nat. Prod. 2011; 74:1508-1512. [PubMed: 21534540]

8. Kujubu DA, Fletcher BS, Varnum BC, Lim RW, Herschman HR. J. Biol. Chem. 1991; 266:1286612872. [PubMed: 1712772]

9. Paula VF, Barbosa LCA, Howarth OW, Demuner AJ, Cass QB, Vieira IJC. Tetrahedron. 1995; 51:12453-12462.

10. Seca AML, Silva AMS, Silvestre AJD, Cavaleiro JAS, Domingues FMJ, Neto CP. Phytochemistry. 2001; 56:759-767. [PubMed: 11314965]

11. Matsuda N, Kikuchi M. Chem. Pharm. Bull. 1996; 44:1676-1679.

12. Kim KH, Kim HK, Choi SU, Moon E, Kim SY, Lee KR. J. Nat. Prod. 2011; 74:2187-2192. [PubMed: 21936523]

13. Guo J, Zhang J, Wang W, Liu T, Xin Z. Eur. Food Res. Technol. 2015; 241:37-47.

14. Yoshioka T, Inokuchi T, Fujioka S, Kimura YZ. Naturforsch., C: J. Biosci. 2004; 59:509-514.

15. Wang SM, Kadota S, Liu ZQ, Liu SY. Nat. Prod. Res. Dev. 2005; 17:131-137.

16. Wu JF, Chen SB, Wu LJ, Chen SL, Tu PF. Chin. J. Chin. Mater. Med. 2007; 32:819-821.

17. Zhang DW, Dai SJ, Liu WH, Li GH. Zhongguo Tianran Yaowu. 2010; 8:196-198.

18. Huang SC, Yen GC, Chang LW, Yen WJ, Duh PD. J. Agric. Food Chem. 2003; 51:2380-2383. [PubMed: 12670184]

19. Ekaprasada MT, Nurdin H, Ibrahim S. Indon. J. Chem. 2009; 9:457-460.

20. Cutillo F, Abrosca B, Greca MD, Fiorentino A, Zarrelli AJ. Agric. Food Chem. 2003; 51:61656172.

21. Besombes S, Robert D, Utille JP, Taravel FR, Mazeau KJ. Agric. Food Chem. 2003; 51:34-42.

22. Xiong L, Zhu C, Li Y, Tian Y, Lin S, Yuan S, Hu J, Hou Q, Chen N, Yang Y, Shi JJ. Nat. Prod. 2011; 74:1188-1200.

23. Kijima K, Oha H, Ide T, Ogimi, Hirata CE, Takushi A, Takeda Y. Phytochemistry. 1998; 48:669_ 676. 
24. Dang Z, Zhu L, Lai W, Bogerd H, Lee KH, Huang L, Chen CH. ACS Med. Chem. Lett. 2016 in press. 


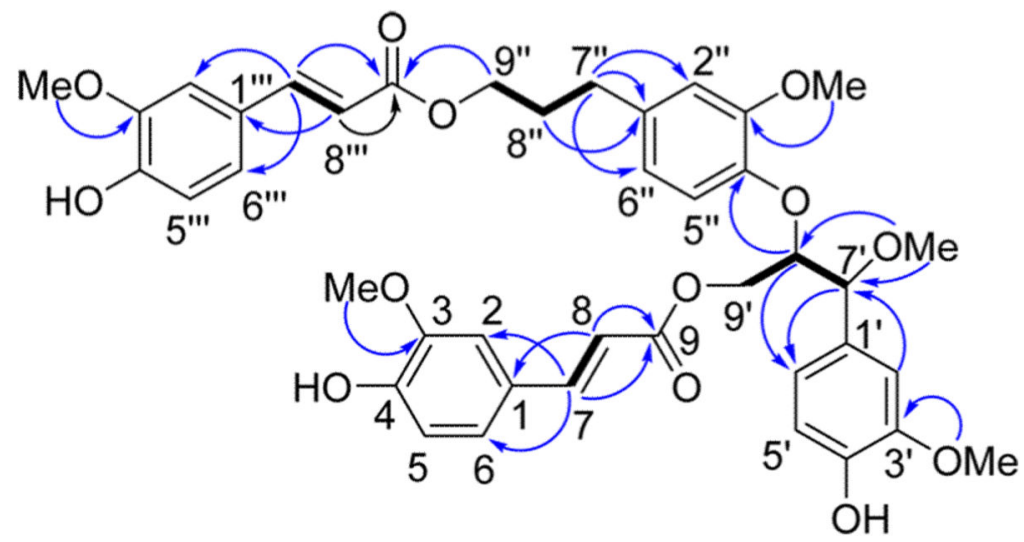

Figure 1.

Key ${ }^{1} \mathrm{H}-{ }^{1} \mathrm{H}$ COSY $(-)$ and $\mathrm{HMBC}(\rightarrow)$ correlations of $\mathbf{1}$. 


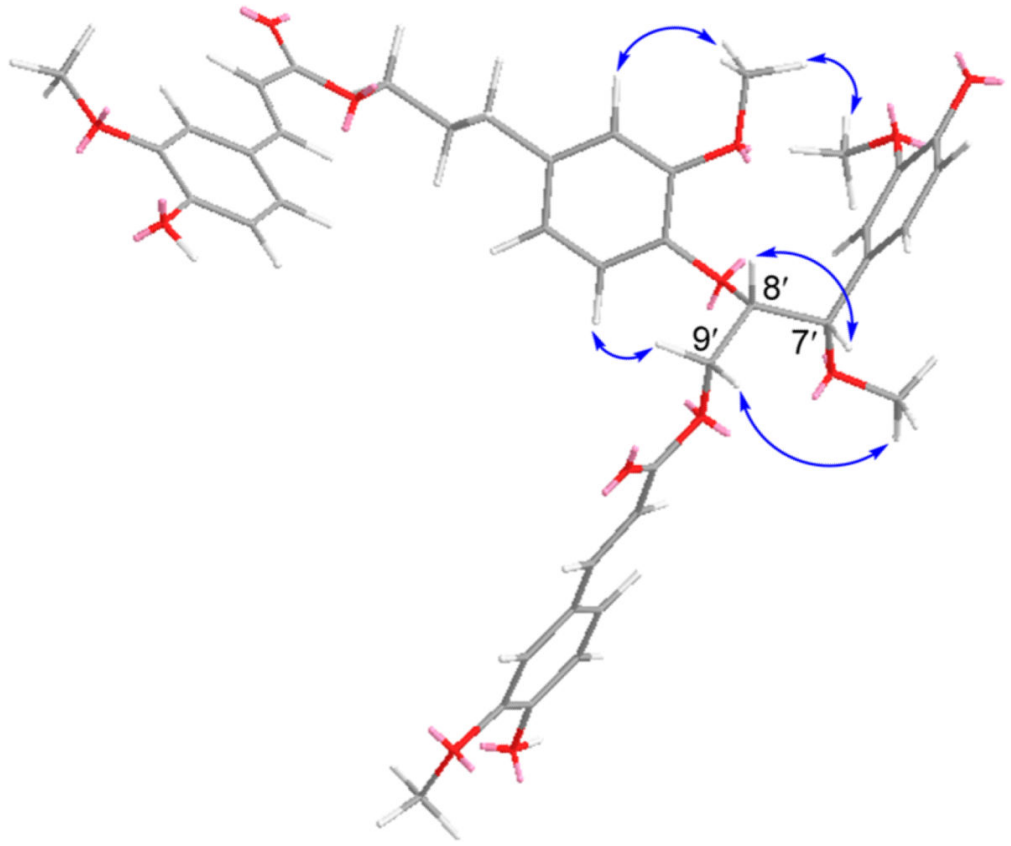

Figure 2.

Key NOE correlations $(\leftrightarrow)$ of $\mathbf{1}$. 


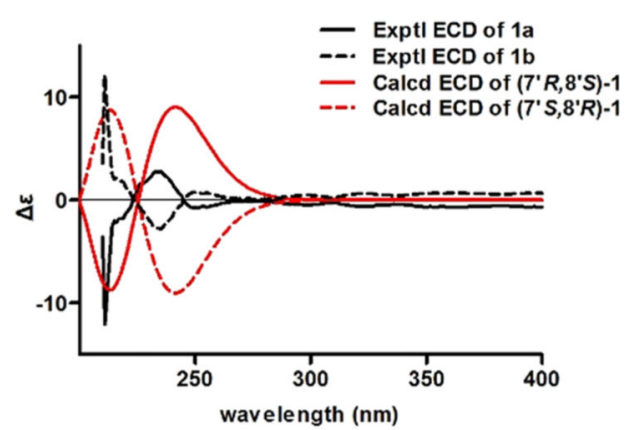

(a)

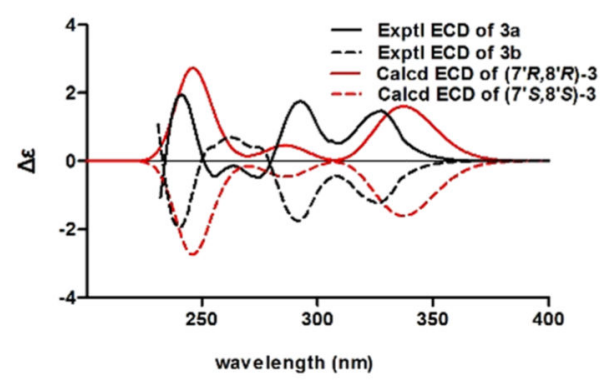

(c)

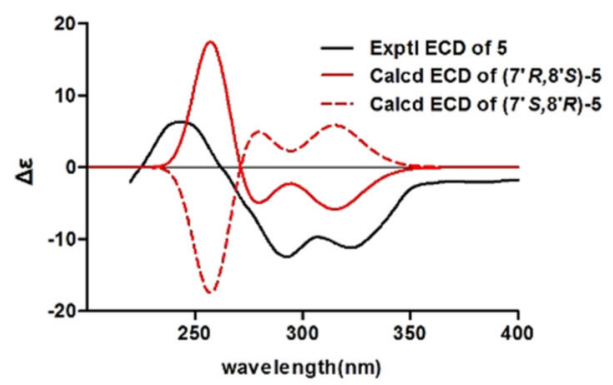

(e)

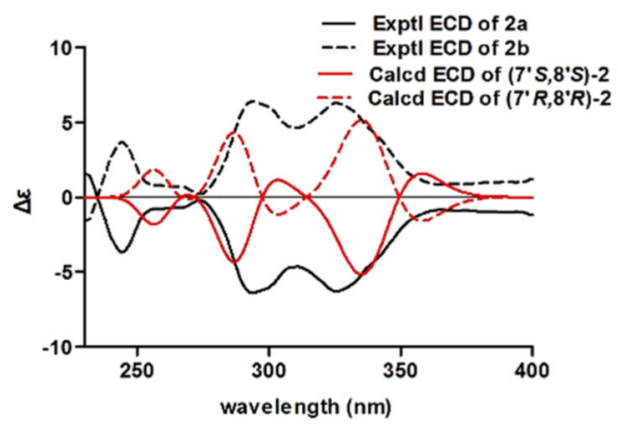

(b)

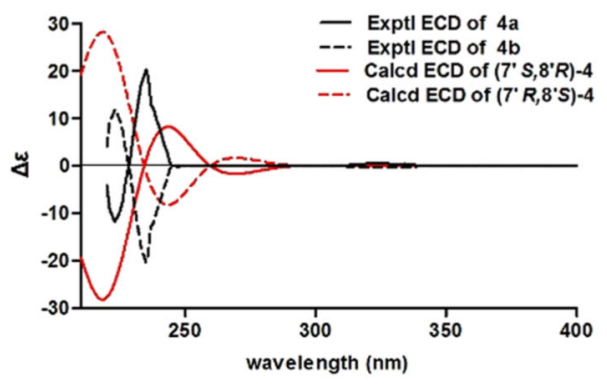

(d)

\section{Figure 3.}

(a) Experimental ECD spectra of (-)- and (+)-erythro- $7^{\prime}$-methylcarolignan E $(\mathbf{1 a} / \mathbf{1 b})$ in MeCN and calculated ECD spectra of $\left(S^{\prime}, R^{\prime}\right)-\mathbf{1}$ and $\left(R^{\prime}, S^{\prime}\right)-\mathbf{1}$. (b) Experimental ECD spectra of (-)- and (+)-threo-7'-methylcarolignan E (2a/2b) in MeCN and calculated ECD spectra of $\left(R^{\prime}, R^{\prime}\right)-2$ and $\left(S^{\prime}, S^{\prime}\right)$-2. (c) Experimental ECD spectra of (+)- and (-)-threo-carolignan E $(\mathbf{3 a} / \mathbf{3 b})$ in MeCN and calculated ECD spectra of $\left(R^{\prime}, R^{\prime}\right)-\mathbf{3}$ and $\left(S^{\prime}, S^{\prime}\right)-\mathbf{3}$. (d) Experimental ECD spectra of (+)- and (-)-erythro-carolignan E (4a/4b) in MeCN and calculated ECD spectra of $\left(S^{\prime}, R^{\prime}\right)-\mathbf{4}$ and $\left(R^{\prime}, S^{\prime}\right)-\mathbf{4}$. (e) Experimental ECD spectra of (-)-erythro-carolignan Z (5) in MeCN and calculated ECD spectra of $\left(R^{\prime}, S^{\prime}\right)-5$ and $\left(S^{\prime}, R^{\prime}\right)-5$. The calculated ECD spectra were computed at the B3LYP/6-311++G(d,p) level. 


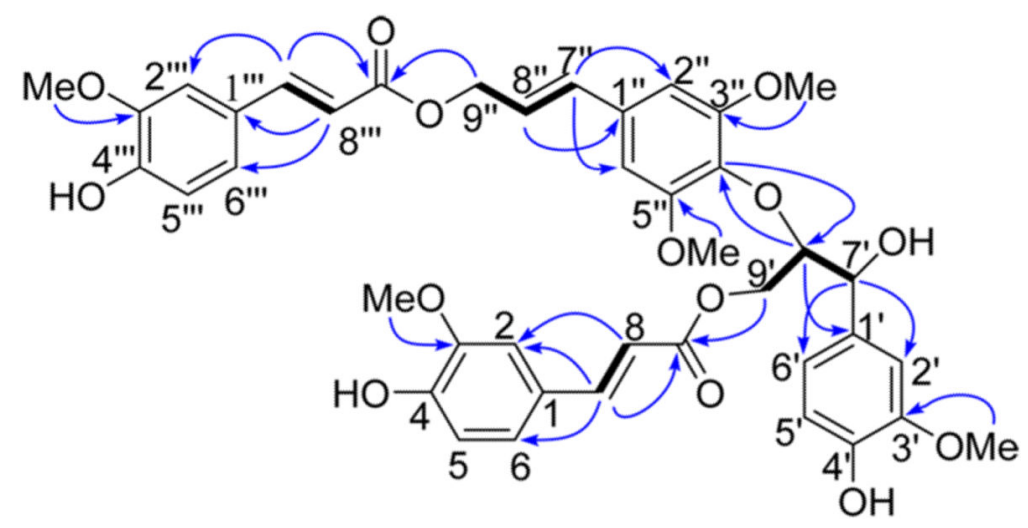

Figure 4.

Key ${ }^{1} \mathrm{H}-{ }^{1} \mathrm{H}$ COSY $(-)$ and $\mathrm{HMBC}(\rightarrow)$ correlations of 5. 
Table 1

${ }^{1} \mathrm{H}$ NMR Spectroscopic Data (400 MHz, in $\mathrm{CDCl}_{3}$ ) for Compounds $1-5$ ( $\delta_{\mathrm{H}}$ in ppm, $J$ in $\mathrm{Hz}$ )

\begin{tabular}{|c|c|c|c|c|c|}
\hline position & $1 \mathrm{a} / 1 \mathrm{~b}^{a}$ & $2 \mathrm{a} / 2 \mathrm{~b}^{a}$ & 3a & $4 a$ & 5 \\
\hline 2 & $7.02 \mathrm{~d}(1.9)$ & $7.00 \mathrm{~d}(1.9)$ & $7.01 \mathrm{~d}(1.9)$ & $6.91 \mathrm{~d}(1.8)$ & $7.00 \mathrm{~d}(2.0)$ \\
\hline 5 & $6.85 \mathrm{~d}(8.2)$ & $6.89 \mathrm{~d}(8.2)$ & $6.88 \mathrm{~d}(8.3)$ & $6.87 \mathrm{~d}(8.3)$ & $6.73 \mathrm{~d}(8.3)$ \\
\hline 6 & $7.05 \mathrm{~d}(1.9,8.2)$ & $7.06 \mathrm{~d}(1.9,8.2)$ & $7.05 \mathrm{~d}(1.9,8.3)$ & $7.00 \mathrm{~m}$ & $7.05 \mathrm{~d}(2.0,8.3)$ \\
\hline 7 & $7.48 \mathrm{~d}(15.9)$ & $7.48 \mathrm{~d}(15.9)$ & $7.59 \mathrm{~d}(15.9)$ & $7.59 \mathrm{~d}(15.9)$ & $7.64 \mathrm{~d}(15.9)$ \\
\hline 8 & $6.23 \mathrm{~d}(15.9)$ & $6.26 \mathrm{~d}(15.9)$ & $6.24 \mathrm{~d}(15.9)$ & $6.21 \mathrm{~d}(15.9)$ & $6.21 \mathrm{~d}(15.9)$ \\
\hline $2^{\prime}$ & $6.93 \mathrm{~m}$ & $6.89 \mathrm{~d}(1.8)$ & $7.04 \mathrm{~m}$ & $7.01 \mathrm{~m}$ & $6.98 \mathrm{~m}$ \\
\hline $5^{\prime}$ & $6.90 \mathrm{~d}(8.2)$ & $6.87 \mathrm{~d}(8.1)$ & $6.87 \mathrm{~d}(8.1)$ & $6.89 \mathrm{~d}(8.1)$ & $6.96 \mathrm{~d}(8.2)$ \\
\hline $6^{\prime}$ & $6.86 \mathrm{~m}$ & $6.85 \mathrm{dd}(1.8,8.1)$ & $6.75 \mathrm{dd}(1.8,8.1)$ & $6.84 \mathrm{dd}(2.0,8.0)$ & $6.87 \mathrm{~d}(1.7,8.2)$ \\
\hline $7^{\prime}$ & $4.52 \mathrm{~d}(3.0)$ & $4.25 \mathrm{t}(6.3)$ & $4.91 \mathrm{~d}(8.1)$ & $4.90 \mathrm{~d}(3.3)$ & $4.88 \mathrm{~d}(3.1)$ \\
\hline $8^{\prime}$ & $4.48 \mathrm{~m}$ & $4.43 \mathrm{~m}$ & $4.20 \mathrm{~m}$ & $4.44 \mathrm{~m}$ & $4.55 \mathrm{~m}$ \\
\hline \multirow[t]{2}{*}{$9^{\prime}$} & $4.11 \mathrm{dd}(4.7,11.6)$ & $4.13 \mathrm{~m}$ & $4.13 \mathrm{dd}(4.8,12.1)$ & $4.26 \mathrm{~m}$ & $4.83 \mathrm{~d}(6.4)$ \\
\hline & $4.31 \mathrm{dd}(2.8,11.6)$ & $4.44 \mathrm{~m}$ & $4.34 \mathrm{dd}(3.4,12.1)$ & $4.48 \mathrm{~m}$ & \\
\hline $2^{\prime \prime}$ & $6.68 \mathrm{~d}(1.8)$ & $6.63 \mathrm{~d}(1.8)$ & $6.72 \mathrm{~d}(1.8)$ & $6.75 \mathrm{~d}(1.8)$ & $6.60 \mathrm{~d}(1.8)$ \\
\hline $5^{\prime \prime}$ & $6.90 \mathrm{~m}$ & $6.84 \mathrm{~d}(8.0)$ & $6.91 \mathrm{~d}(8.0)$ & $6.95 \mathrm{~d}(8.0)$ & \\
\hline $6^{\prime \prime}$ & $6.80 \mathrm{dd}(1.8,8.1)$ & $6.81 \mathrm{dd}(1.8,8.0)$ & $6.85 \mathrm{dd}(1.8,8.0)$ & $6.81 \mathrm{dd}(1.8,8.0)$ & $6.60 \mathrm{~d}(1.8)$ \\
\hline $7^{\prime \prime}$ & $2.62 \mathrm{t}(6.5)$ & $2.58 \mathrm{~m}$ & $2.68 \mathrm{t}(7.9)$ & $2.68 \mathrm{t}(6.5)$ & $6.63 \mathrm{~d}(15.7)$ \\
\hline $8^{\prime \prime}$ & $1.96 \mathrm{~m}$ & $1.91 \mathrm{~m}$ & $2.00 \mathrm{~m}$ & $1.99 \mathrm{~m}$ & $6.30 \mathrm{~d}(15.7)$ \\
\hline \multirow[t]{2}{*}{$9^{\prime \prime}$} & $4.15 \mathrm{t}(6.5)$ & $4.13 \mathrm{t}(6.4)$ & $4.20 \mathrm{t}(6.0)$ & $4.19 \mathrm{t}(6.5)$ & $4.25 \mathrm{~d}(3.7)$ \\
\hline & & & & & $4.44 \mathrm{~m}$ \\
\hline $2^{\prime \prime \prime}$ & $7.00 \mathrm{~d}(1.8)$ & $7.00 \mathrm{~d}(1.8)$ & $7.01 \mathrm{~d}(1.8)$ & $7.01 \mathrm{~m}$ & $6.93 \mathrm{~d}(1.7)$ \\
\hline $5^{\prime \prime \prime}$ & $6.91 \mathrm{~d}(8.1)$ & $6.94 \mathrm{~d}(8.1)$ & $6.91 \mathrm{~d}(8.1)$ & $6.95 \mathrm{~d}(7.9)$ & $6.75 \mathrm{~d}(8.2)$ \\
\hline $6^{\prime \prime \prime}$ & $7.05 \mathrm{dd}(1.8,8.1)$ & $7.02 \mathrm{dd}(1.8,8.1)$ & $7.01 \mathrm{dd}(1.8,8.1)$ & $7.06 \mathrm{dd}(1.8,8.3)$ & $7.08 \mathrm{dd}(1.7,8.2)$ \\
\hline $7^{\prime \prime \prime}$ & $7.59 \mathrm{~d}(15.9)$ & $7.59 \mathrm{~d}(15.9)$ & $7.51 \mathrm{~d}(15.9)$ & $7.49 \mathrm{~d}(15.9)$ & $7.69 \mathrm{~d}(15.9)$ \\
\hline $8^{\prime \prime \prime}$ & $6.27 \mathrm{~d}(15.9)$ & $6.28 \mathrm{~d}(15.9)$ & $6.28 \mathrm{~d}(15.9)$ & $6.28 \mathrm{~d}(15.9)$ & $6.23 \mathrm{~d}(15.9)$ \\
\hline $\mathrm{OCH}_{3}-3$ & $3.90 \mathrm{~s}$ & $3.86 \mathrm{~s}$ & $3.92 \mathrm{~s}$ & $3.90 \mathrm{~s}$ & $3.85 \mathrm{~s}$ \\
\hline $\mathrm{OCH}_{3}-3^{\prime}$ & $3.82 \mathrm{~s}$ & $3.78 \mathrm{~s}$ & $3.88 \mathrm{~s}$ & $3.86 \mathrm{~s}$ & $3.87 \mathrm{~s}$ \\
\hline $\mathrm{OCH}_{3}-3^{\prime \prime}$ & $3.72 \mathrm{~s}$ & $3.72 \mathrm{~s}$ & $3.84 \mathrm{~s}$ & $3.86 \mathrm{~s}$ & $3.90 \mathrm{~s}$ \\
\hline $\mathrm{OCH}_{3}-3^{\prime \prime \prime}$ & $3.90 \mathrm{~s}$ & $3.86 \mathrm{~s}$ & $3.92 \mathrm{~s}$ & $3.90 \mathrm{~s}$ & $3.85 \mathrm{~s}$ \\
\hline $\mathrm{OCH}_{3}-5^{\prime \prime}$ & & & & & $3.90 \mathrm{~s}$ \\
\hline $\mathrm{OCH}_{3}-7^{\prime}$ & $3.27 \mathrm{~s}$ & $3.25 \mathrm{~s}$ & $3.25 \mathrm{~s}$ & $3.25 \mathrm{~s}$ & \\
\hline
\end{tabular}

${ }^{a} \mathbf{1 a} / \mathbf{1} \mathbf{b}$ and $\mathbf{2 a} / \mathbf{2 b}$ showed the same ${ }^{1} \mathrm{H}$ NMR data. 
Table 2

${ }^{13} \mathrm{C}$ NMR $(100 \mathrm{MHz})$ Data $(\delta)$ of Compounds $1-5\left(\delta_{\mathrm{C}}\right.$ in ppm)

\begin{tabular}{|c|c|c|c|c|c|}
\hline position & $1 \mathrm{a} / 1 \mathrm{~b}^{a}$ & $2 \mathrm{a} / 2 \mathrm{~b}^{a}$ & $3 a$ & $4 a$ & 5 \\
\hline 1 & 127.1 & 127.1 & 127.1 & 127.0 & 127.1 \\
\hline 2 & 109.3 & 109.3 & 109.6 & 109.5 & 109.5 \\
\hline 3 & 146.9 & 146.9 & 147.0 & 147.0 & 147.0 \\
\hline 4 & 148.2 & 148.1 & 148.3 & 148.2 & 148.3 \\
\hline 5 & 114.3 & 114.3 & 114.6 & 114.3 & 115.0 \\
\hline 6 & 123.3 & 123.3 & 123.3 & 123.3 & 123.3 \\
\hline 7 & 145.3 & 145.2 & 145.6 & 145.4 & 145.0 \\
\hline 8 & 115.6 & 115.5 & 115.6 & 115.6 & 115.3 \\
\hline 9 & 167.1 & 167.3 & 167.0 & 167.3 & 167.2 \\
\hline $1^{\prime}$ & 130.0 & 130.3 & 131.4 & 131.2 & 130.8 \\
\hline $2^{\prime}$ & 109.9 & 110.0 & 109.5 & 109.0 & 108.6 \\
\hline $3^{\prime}$ & 146.9 & 146.9 & 146.9 & 146.8 & 146.8 \\
\hline $4^{\prime}$ & 145.8 & 145.6 & 145.8 & 145.3 & 145.6 \\
\hline $5^{\prime}$ & 114.9 & 114.9 & 114.9 & 114.9 & 114.3 \\
\hline $6^{\prime}$ & 120.6 & 120.6 & 120.9 & 121.0 & 119.0 \\
\hline $7^{\prime}$ & 83.5 & 82.8 & 74.6 & 72.3 & 71.9 \\
\hline $8^{\prime}$ & 82.3 & 82.6 & 86.6 & 84.7 & 83.7 \\
\hline $9^{\prime}$ & 63.9 & 63.8 & 63.2 & 62.8 & 62.7 \\
\hline $1^{\prime \prime}$ & 136.0 & 136.2 & 137.6 & 137.6 & 130.9 \\
\hline $2^{\prime \prime}$ & 112.6 & 112.6 & 112.5 & 112.6 & 103.9 \\
\hline $3^{\prime \prime}$ & 150.9 & 151.0 & 151.0 & 151.6 & 153.7 \\
\hline $4^{\prime \prime}$ & 146.7 & 146.8 & 146.3 & 145.3 & 134.1 \\
\hline $5^{\prime \prime}$ & 118.9 & 119.2 & 120.6 & 119.5 & 153.7 \\
\hline $6^{\prime \prime}$ & 121.0 & 121.2 & 121.2 & 121.3 & 103.9 \\
\hline $7^{\prime \prime}$ & 32.1 & 32.0 & 32.2 & 32.2 & 134.0 \\
\hline $8^{\prime \prime}$ & 30.6 & 30.6 & 30.62 & 30.6 & 123.8 \\
\hline $9^{\prime \prime}$ & 63.9 & 63.9 & 63.8 & 63.9 & 65.0 \\
\hline $1^{\prime \prime \prime}$ & 127.1 & 127.1 & 127.1 & 127.1 & 127.2 \\
\hline $2^{\prime \prime \prime}$ & 109.5 & 109.5 & 109.6 & 109.6 & 109.4 \\
\hline $3^{\prime \prime \prime}$ & 146.9 & 146.9 & 147.0 & 147.0 & 147.0 \\
\hline $4^{\prime \prime \prime}$ & 148.1 & 148.1 & 148.2 & 148.2 & 148.1 \\
\hline $5^{\prime \prime \prime}$ & 114.9 & 114.9 & 114.9 & 115.0 & 114.9 \\
\hline $6^{\prime \prime \prime}$ & 123.4 & 123.5 & 123.4 & 123.4 & 123.3 \\
\hline $7^{\prime \prime \prime}$ & 145.1 & 145.2 & 145.2 & 145.2 & 145.0 \\
\hline $8^{\prime \prime \prime}$ & 115.2 & 115.6 & 114.9 & 115.2 & 115.6 \\
\hline $9^{\prime \prime \prime}$ & 167.5 & 167.6 & 167.5 & 167.5 & 167.2 \\
\hline $\mathrm{OCH}_{3}-3$ & 56.2 & 56.2 & 56.2 & 56.2 & 56.2 \\
\hline $\mathrm{OCH}_{3}-3^{\prime}$ & 56.2 & 56.1 & 56.1 & 56.2 & 56.2 \\
\hline
\end{tabular}

J Nat Prod. Author manuscript; available in PMC 2017 March 25. 


\begin{tabular}{lrrrrr}
\hline position & $\mathbf{1 a} / \mathbf{1} \mathbf{b}^{\boldsymbol{a}}$ & $\mathbf{2 a / 2 \mathbf { b } ^ { a }}$ & $\mathbf{3 a}$ & $\mathbf{4 a}$ & $\mathbf{5}$ \\
$\mathrm{OCH}_{3}-3^{\prime \prime}$ & 56.0 & 55.9 & 56.0 & 56.1 & 56.4 \\
$\mathrm{OCH}_{3}-3^{\prime \prime \prime}$ & 56.2 & 56.2 & 56.2 & 56.2 & 56.2 \\
$\mathrm{OCH}_{3}-5^{\prime \prime}$ & & & & & 56.4 \\
$\mathrm{OCH}_{3}-7^{\prime}$ & 57.4 & 57.4 & & & \\
\hline
\end{tabular}

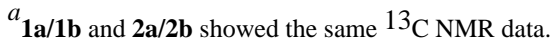


Table 3

Anti-HIV Data of the Isolates from E. sikkimensis

\begin{tabular}{lcccc}
\hline compound & $\mathbf{E C}_{\mathbf{5 0}}(\boldsymbol{\mu M})$ & number of tests & $\mathbf{C C}_{\mathbf{5 0}}(\boldsymbol{\mu M})$ & $\mathbf{S I}\left(\mathbf{C C}_{\mathbf{5 0}} / \mathbf{E C}_{\mathbf{5 0}}\right) \boldsymbol{b}$ \\
$\mathbf{1 a}$ & $6.3 \pm 2.1$ & 3 & $21 \pm 1.1$ & 3.3 \\
$\mathbf{1 b}$ & $5.3 \pm 1.2$ & 3 & $17 \pm 1.2$ & 3.2 \\
$\mathbf{2 a}^{a}$ & $>10$ & 1 & $>10$ & \\
$\mathbf{2 b}^{a}$ & $>10$ & 1 & $>10$ & \\
$\mathbf{5}^{a}$ & $>10$ & 1 & $>10$ & \\
$\mathbf{8}^{a}$ & $>10$ & 1 & $>10$ & \\
$\mathbf{9}^{a}$ & $>10$ & 1 & $>10$ & \\
$\mathrm{AZT}^{a}$ & $0.004 \pm 0.0012$ & 3 & $>0.1$ & $>25$ \\
\hline
\end{tabular}

${ }^{a}$ The highest concentration tested was $10 \mu \mathrm{M}$ for all the samples in the first test; $0.1 \mu \mathrm{g} / \mathrm{mL}$ for the control AZT. Testing concentration ranges were adjusted in subsequent tests based on potency.

${ }^{b}$ SI is the selective index, $\mathrm{SI}=\mathrm{CC}_{50} / \mathrm{EC}_{50}$. 